\title{
PERAN RSUD PAMBALAH BATUNG AMUNTAI DALAM IMPLEMENTASI PROGRAM BPJS KESEHATAN DI HULU SUNGAI UTARA
}

\author{
Jumaidi \\ Sekolah Tinggi Ilmu Administrasi (STIA) Amuntai \\ Email: jumaidi.albanjari@yahoo.com
}

\begin{abstract}
The issues discussed in this study were the implementation of BPJS program on health in RSUD of Pambalah Batung, Amuntai. It is inspired by the complaints of patients who were admitted to redeem the drug, the number of beds and rooms which was not adequate as well as there were many facilities and infrastructures which were still in bad condition, and there were many people who were not aware of the availability of BPJS program on health. The samples of data sources used purposive sampling technique. As many as 10 people were considered to have strong relations with the issues examined. The data were collected by observations, interviews, and documentation. The survey results revealed: the constraint from the aspect of the unclear communication which resulted in the delays of service process carried out by the Executive of RSUD, the aspect of resources interms of facilities which was still in sufficient because there were many health facilities which were not functioning properly and in damaged condition.It is suggested to socialize BPJS on health program more often by RSUD of Pambalah Batung through flags, banners, and localtelevision, toad health facilities for BPJS patients especially in patient and sanitary rooms, to repair damaged facilities. The addition of internet (wifi), particularly for Emergency Room (ER) is required when information on JKN program is in need.
\end{abstract}

Keywords: implementation, BPJS Health, constraints

\section{PENDAHULUAN}

Setiap masyarakat indonesia mempunyai hak dalam mendapatkan pelayanan dan akses yang sama dalam bidang kesehatan, baik keamanan, fasilitas, mutu dan keterjangkauan biaya. Sebaliknya, setiap masyarakat juga mempunyai kewajiban ikut serta dalam Program Jaminan Kesehatan Nasional (JKN) yang diselenggarakan oleh Pemerintah.

Untuk mewujudkan rencana kesehatan global tersebut, pemerintah mempunyai tanggungjawab atas pelaksanaan Jaminan Kesehatan Nasional (JKN). Usaha kearah tersebut, sudah beberapa dekade dirintis oleh Pemerintah dengan melaksanakan beberapa program dalam bentuk jaminan sosial dibidang kesehatan, seperti Asuransi Kesehatan (askes) dan Jaminan Sosial Ketenagakerjaan (jamsostek) yang melayani Pegawai Negeri Sipil (PNS), veteran, pensiun dan pegawai perusahaan
(Swasta). Sedangkan untuk masyarakat tidak mampu, Pemerintah memberikan jaminan kesehatan melalui program Jaminan Kesehatan Masyarakat (Jamkesmas) dan Jaminan Kesehatan Daerah (Jamkesda). Tetapi demikian, Program tersebut masih terfragmentasi, terbagibagi dalam beberapa program yang dilaksanakan oleh institusi pemerintah yang berbeda-beda.

Dibelahan dunia, program jaminan sosial kesehatan telah dilaksanakan. Di Indonesia sendiri, jaminan sosial merupakan amanah dari konstitusi Indonesia yang termaktub dalam pembukaan UUD 1945 dan dalam UndangUndang itu sendiri dalam Pasal 28 ayat 3 dan Pasal 34 ayat 1 bahwa Negara memberikan jaminan bagi seluruh penduduk Indonesia untuk mendapatkan jaminan dan kesejahteraan sosial. Pada tahun 2004 terbitlah Undang-Undang tentang Sistem Jaminan Sosial Nasional (SJSN) yang memberikan pertimbangan utama untuk 
memberikan jaminan sosial yang menyeluruh bagi masyarakat Indonesia.

Pada tahun 2011 terbitlah UndangUndang Nomor 24 Tahun 2011, tindak lanjut dari Undang-Undang SJSN yang megatur tentang Badan Penyelenggara Jaminan Sosial (BPJS). Dalam Undang-Undang tersebut mengatur tentang perubahan badan penyelenggara jaminan sosial yang telah ada menjadi Badan Penyelenggara Jaminan Sosial (BPJS) Kesehatan dan Badan Penyelenggara Jaminan Sosial (BPJS) Ketenagakerjaan.

Pada tanggal 1 Januari 2014, UndangUndang tentang BPJS Kesehatan dan BPJS Ketenagakerjaan resmi diimplementasikan setelah melalui tahapan sosialisasi dan pembenahan selama 3 tahun sejak terbitnya UU SJSN pada tahun 2011. Dalam UU tersebut dijelaskan bahwa seluruh rakyat Indonesia mempunyai kewajiban untuk berpartisipasi sebagai peserta atau anggota dalam program tersebut dan mempunyai kewajiban membayar iurannya. Bagi masyarakat tidak mampu dan fakir miskin, Pemerintah diberikan amanah untuk menanggung iurannya bagi masyarakat yang dikategorikan sebagai Penerima Bantuan Iuran (PBI).

Kinerja BPJS kedepan yang bertujuan untuk kemajuan JKN sangat bergantung pada dukungan dan kepercayaan publik. Dewan Pengawas dan Dewan Jaminan Sosial Nasional (DJSN) akan terus memantau dan mengawasi segala aspek penyelenggaraan JKN oleh BPJS Kesehatan.

Dalam Praktiknya implementasi kebijakan seringkali menjadi sebuah proses yang begitu kompleks serta bermuatan politik dan diwarnai dengan intervensi dari berbagai kepentingan. Implementasi kebijakan itu sendiri menjadi tahapan yang sangat penting dalam keseluruhan struktur kebijakan yang ada, karena melalui prosedur inilah proses kebijakan dapat diketahui tingkat keberhasilan atau tidaknya pencapaian tujuan yang ingin dicapai.

Solichin A. Wahab (2005:64) mengemukan beberapa pengertian mengenai implementasi kebijakan

a. Kamus Webster, merumuskan secara pendek bahwa mengimplementasikan berarti menyediakan sarana untuk melaksanakan sesuatu; menimbulkan dampak/akibat terhadap sesuatu.

b. Menurut Van Meter dan Van Horn (dalam Abdul Wahab, 2005) merumuskan proses implementasi ini sebagai tindakan-tindakan yang dilakukan baik oleh individuindividu/pejabat-pejabat atau kelompokkelompok Pemerintah atau swasta yang diarahkan pada tercapainya tujuan-tujuan yang telah digariskan dalam keputusan kebijakan.

c. Menurut Daniel A.Mazmanian dan Paul A. Sabatier (dalam Abdul Wahab, 2005), menjelaskan makna implementasi ini dengan mengatakan bahwa memahami apa yang senyatanya terjadi sesudah suatu program dinyatakan berlaku atau dirumuskan merupakan focus perhatian implementasi kebijakan, yakni kejadian-kejadian dan kegiatan-kegiatan yang timbul sesudah disahkannya pedoman-pedoman kebijaksanaan Negara, yang mencakup baik usaha-usaha untuk mengadministrasikannya maupun untuk menimbulkan akibat/dampak nyata pada masyarakat atau kejadiankejadian.

Orang sering beranggapan bahwa implementasi hanya merupakan pelaksanaan dari apa yang telah diputuskan legeslatif atau para pengambil keputusan. Akan tetapi betapapun baiknya rencana yang telah dibuat tetap tidak ada gunanya apabila tidak dilaksanakan dengan baik dan benar.

Dalam praktiknya implementasi kebijakan publik merupakan sebuah proses yang begitu komplek dan sering kali bermuatan politik berupa tekanan dari berbagai oknum yang berkepentingan. Bahkan Eugene Bardach menganggap jika sebuah kebijakan yang kelihatannya bagus di atas kertas, tidaklah mudah untuk merumuskannya dalam kata-kata yang kedengarannya mengenakkan di telinga semua orang, apalagi untuk melaksanakannya agar mampu memuaskan semua orang.

Dalam mengkaji suatu implementasi kebijakan publik maka diperlukan variabel dan faktor-faktor yang mempengaruhinya, berupa model kebijakan guna menyederhanakan pemahaman konsep suatu implementasi kebijakan. Terdapat banyak model yang dapat 
dipakai untuk menganalisis sebuah implementasi kebijakan, salah satunya adalah model Model George C. Edward III.

Dalam model George C. Edward III ada empat faktor yang berperan penting dalam pencapaian keberhasilan implementasi. Faktorfaktor yang mempengaruhi keberhasilan atau kegagalan implementasi kebijakan yaitu faktor Komunikasi, Sumber Daya, Disposisi dan struktur Birokrasi.

Implementasi akan efektif jika para pembuat keputusan sudah mengetahui dan memahami apa yang akan mereka kerjakan. Pemahamam tentang apa yang akan mereka kerjakan ini dapat berjalan dengan baik jika komunikasi yang terjalin terbina dengan baik

Selain itu kebijakan menuntut adanya sumber daya baik yang berupa dana maupun insentif yang lain yang kemungkinan dapat mendorong terlaksananya implementasi secara efektif. Edward III mengatakan bahwa: bagaimanapun jelas dan konsistensinya ketentuan dan aturan serta bagaimanapun akuratnya penyampaian ketentuan atau aturan tersebut, jika para pelaksana kebijakan yang bertanggung jawab untuk melaksanakan kebijakan kurang mempunyai sumber daya untuk melaksanakan kebijakan secara efektif maka implementasi kebijakan tersebut tidak akan berjalan efektif.

Tersedianya sumber daya yang memadai akan mendukung dalam pelaksanan suatu program untuk dapat mencapai tujuan yang diinginkan. Sumber daya tersebut dapat berupa biaya, perlengkapan yang dibutuhkan maupun Sumber Daya Manusianya.

Kecenderungan perilaku atau karakteristik dari pelaksana kebijakan juga berperan penting untuk mewujudkan implementasi yang sesuai dengan tujuan, misalnya kejujuran dan komitmen yang tinggi. Kejujuran menjadi arahan setiap pelaksana kebijakan untuk berada dalam program yang telah ditentukan, sedangkan komitmen yang tinggi akan membuat para implementor untuk selalu antusias dalam menerapkan peraturan yang telah ditetapkan.

Suatu sistem memerlukan kerja sama antar stake holder dan juga masyarakat.
Masyarakat merupakan pemilik kepentingan yang paling utama, dan harus memiliki kesadaran dalam mematuhi aturan yang telah dibentuk. Instansi yang ditunjuk sebagai badan penyelenggara memiliki tanggungjawab penuh dalam melaksanakan dan memberikan jaminan sosial bagi rakyat Indonesia.

Birokrasi pemerintah adalah institusi yang kuat eksistensinya karena mempunyai kewenangan yang besar dan begitu luas memiliki sumber daya yang cukup dalam menjalankan kekuasaannya dibanding dengan organisasi lain dalam sebuah Negara. Birokrasi pemerintahan merupakan institusi yang dominan dalam implementasi kebijakan publik yang mempunyai kepentingan yang berbeda-beda dalam setiap hierarkinya. Itulah sebabnya, birokrasi paling sering bahkan secara keseluruhan menjadi pelaksana kegiatan.

Birokrasi diciptakan sebagai instrumen dalam menangani keperluan-keperluan publik (public affair), mempunyai sejumlah tujuan yang berbeda, fungsinya berada dalam lingkungan yang kompleks dan luas serta bukan kekuatan yang netral dan tidak dalam kendali penuh dari pihak luar. Oleh sebab itu, birokrasi pemerintah menjadi kekuatan dalam mengimplementasikan sebuah kebijakan publik. Dengan demikian, birokrasi mempunyai peranan penting dalam implementasi kebijakan publik. Peranan itu biasanya diterjemahkan dalam pola pembagian tugas dan tanggung jawab yang terkendali.

Demi terselenggaranya program JKN yang merata diseluruh Indonesia, maka diperlukan kesiapan yang dilakukan oleh pemangku kepentingan (stakeholder) seperti PT. Askes, Dinas Kesehatan, Rumah Sakit Umum Daerah, Puskesmas, PNS (pengguna askes sosial), juga pengguna Jamkesmas dan Jamkesda. Penelitian ini bertujuan untuk mendapatkan informasi tentang Implementasi Program BPJS Kesehatan di Hulu Sungai Utara melalui dari sistem informasi yang diberikan kepada masyarakat (sosialisasi), kesiapan stakeholder dalam pelaksanaan dilihat dari kesiapan fasilitas kesehatan dalam memenuhi syarat kredensial BPJS Kesehatan, kesiapan dalam menerima sistem pembiayaan, dan proses regulasi. 
Dalam konteks implementasi Program BPJS Kesehatan pada RSUD Pambalah Batung, maka dapat dideskripsikan bahwa yang dimaksud tingkat komunikasi (Sosialisasi) tersebut adalah sebuah proses penyampaian pesan-pesan kebijakan yang dilakukan oleh RSUD Pambalah Batung kepada masyarakat dalam rangka tercapainya tujuan-tujuan yang ingin dicapai dari adanya Program tersebut. Sebagai suatu sistem yang baru saja diimplementasikan, BPJS Kesehatan di Kabupaten Hulu Sungai Utara masih jauh dari sempurna, permasalahan pun mulai mencuat kepermukaan. Hal ini dikarenakan kurangnya sosialisasi oleh stakeholder kepada masyarakat, sehingga menimbulkan ketidakpahaman bagi masyarakat akan program BPJS Kesehatan tersebut.

Penyampaian informasi tentang program BPJS Kesehatan, merupakan tahapan yang penting yang harus dilakukan oleh pihak terkait. Hal ini menyangkut kejelasan pelayanan yang didapat masyarakat sebagai anggota BPJS Kesehatan tersebut. Masalah itu, justru muncul pada unsur pengaplikasiannya, terutama pada aspek rujukan, besaran biaya dan kepesertaan.

Sebagian masyarakat masih banyak yang belum mengetahui teknis mendapatkan pelayanan sesuai dengan prosedur BPJS Kesehatan. Masyarakat yang menjadi peserta yang akan berobat ke RSUD Pambalah Batung harus mendapatkan rujukan dari Puskesmas/klinik, atau dokter. Sebagian masyarakat belum mengetahui tentang sistem rujukan tersebut.

Masalah lainnya dalam hal komunikasi yang tidak jelas yaitu terkait pelayananpelayanan yang dibiayai oleh BPJS Kesehatan. Karena tidak semua pelayanan kesehatan ditanggung oleh pihak BPJS Kesehatan, termasuk obat-obat yang diberikan kepada pasien peserta BPJS Kesehatan. Di RSUD Pambalah Batung sendiri, ketika obat tersebut bukan tanggungan dari BPJS Kesehatan, maka pasien tersebut disuruh membeli obat yang diresepkan di apotik luar dengan dalih dari Pihak RSUD bahwa obat tersebut habis/tidak ada.

Masalah lainnya, adanya keterlambatan pembayaran dari BPJS kepada RSUD Pambalah Batung. Sehingga obat-obat terlanjur habis dan pelayanan kepada masyarakat pun menjadi terganggu. Di sisi lain, honor atau gaji para aparatur rumah sakit (RSUD Pambalah Batung) juga mengalami keterlambatan pembayaran. Secara psikologis pelayanan yang diberikan akan menjadi seadanya, karena pelayanan yang mereka berikan baru akan dibayar tiga bulan yang akan datang.

Diluar dari polemik halal dan haram Program BPJS Kesehatan, masih banyak permasalahan yang menghinggapi BPJS Kesehatan tersebut, tidak terkecuali di RSUD Pambalah Batung baik dari segi sarana dan prasarana maupun dari segi pelayanannya. Dari segi sarana dan prasarana terlihat tidak seimbangnya jumlah pasien dengan ruangan yang disediakan. Misalkan, anggota BPJS kelas pertama sedang sakit dan memerlukan rawat inap, tetapi ruangan kelas pertama sudah penuh. Tidak menutup kemungkinan pasien kelas pertama tersebut akan mendapatkan pelayanan kelas III, sehingga pasien pun mengeluh karena ketidaksesuaian antara yang mereka bayar dengan yang mereka dapat.

Dari masalah-masalah diatas, peraturan tentang BPJS Kesehatan seakan-seakan diimplementasikan secara terburu-buru. Hal ini bisa dilihat dari perubahan-perubahan tentang peraturan-peraturan sistem pendaftaran BPJS Kesehatan. Diawal implementasi BPJS kesehatan, pendaftaran terlihat loyal untuk semua masyarakat bisa melakukan pendaftaran BPJS ketika mereka membutuhkan, baik ketika sedang sakit maupun tidak, pelayanan pun akan langsung diberikan ketika sudah mendaftar. Enam bulan kemudian peraturan tersebut berubah, ketika masyarakat mendaftar BPJS kesehatan, maka masyarakat tersebut baru bisa mendapatkan pelayanan dari BPJS Kesehatan empat belas hari kemudian.

Peraturan lainnya yang juga berubah yaitu tentang sistem pendaftaran, diawal pengimplementasian BPJS Kesehatan, setiap masyarakat bisa mendaftarkan diri pribadinya masing-masing sebagai anggota. Satu Tahun kemudian peraturan tersebut berubah, bahwa masyarakat yang mendaftar BPJS Kesehatan wajib mendaftarkan dirinya dan anggota keluarganya sebagai peserta kepada BPJS Kesehatan berdasarkan nama-nama yang tertera 
dalam Kartu Keluarga. Tentunya hal ini sangat memberatkan masyarakat dari segi finansial, karena biaya yang dikeluarkan dikalikan dengan jumlah keluarga yang didaftarkan. Aturan ini pulalah yang menjadi pertimbangan masyarakat untuk mendaftar sebagai anggota BPJS Kesehatan, terkait dengan uang yang akan mereka keluarkan perbulan cukup besar, sedangkan undang-undang BPJS mewajibkan setiap masyarakat menjadi anggota Badan Penyelenggara Jaminan Sosial (BPJS) Kesehatan.

Dari permasalahan-permasalahan tersebut mendorong penulis untuk melakukan penelitian tentang Peran RSUD Pambalah Batung dalam Implementasi BPJS Kesehatan di Hulu Sungai Utara.

\section{METODE PENELITIAN}

Metode atau pendekatan yang digunakan dalam penelitian ini adalah pendekatan kualitatif menggunakan data deskriftif. Dengan metode ini suatu fenomena yang diamati akan dapat digali secara dalam dan menyeluruh, sehingga kesimpulan yang diperoleh nantinya akan lebih akurat dan refresentatip serta diharapkan dapat memecahkan permasalahan yang dihadapi. Lokasi penelitian adalah Badan Layanan Umum Daerah Pambalah Batung Amuntai Kabupaten Hulu Sungai Utara. Instrumen penelitian adalah penulis sendiri dengan instrumen pendamping Pegawai RSUD Pambalah Batung Amuntai. Sumber data menggunakan teknik purposive sampling yakni pemilihan sekelompok subjek yang dianggap mempunyai sangkut paut yang erat dengan masalah diteliti sebanyak 10 orang.

Sebagaimana lazimnya penelitian kualitatif, maka yang menjadi instrumen utama dalam penelitian ini adalah individu peneliti sendiri dan menggunakan instrument tambahan berupa Handphone (sebagai alat perekam) serta alat tulis menulis. Data yang dikumpulkan melalui wawancara mendalam kepada informan dan didukung oleh penelaahan atau dokumentasi beberapa peraturan, perundangan-undangan, data penunjang kesehatan (profil Kesehatan) yang terkait dengan penelitian. Teknis analisa data melalui tiga alur, yaitu: Reduksi, Penyajian dan Penarikan kesimpulan dari data yang didapatkan.

Pengecekan data dengan triangulasi sumber dalam penelitian ini dilakukan dengan melakukan wawancara pada pegawai dan masyarakat yang berbeda dari sebelumnya. Teriangulasi Teknik untuk menguji kredibilitas data dilakukan dengan cara mengecek data kepada sumber yang sama dengan teknik yang berbeda. Misalnya data diperoleh dengan wawancara, lalu dicek dengan observasi atau dokumentasi.

\section{HASIL DAN PEMBAHASAN}

Melihat pentingnya tahapan implementasi dari sebuah kebijakan yang telah dijelaskan di atas, tentunya jaminan sosial kesehatan yang dilaksanakan Oleh BPJS Kesehatan sebagai sebuah kebijakan juga perlu untuk di implementasikan agar tidak hanya terlihat rapi di dalam arsip. Dalam pengimplementasiannya di RSUD Pambalah Batung Amuntai perlu kiranya melihat kualitas pelayanan pada instalasi rawat inap kelas III pada RSUD Pambalah Batung amuntai mencakup beberapa unsur pelayanan diantaranya yaitu: prosedur pelayanan, sumber daya \& staf, sarana dan prasarana pelayanan, kecepatan pelayanan.

\section{Prosedur Pelayanan}

Prosedur pelayanan pada instalasi rawat inap pada RSUD Pambalah Batung, baik dari prosedur pelayanan masuk pasien maupun prosedur pelayanan pengambilan obat dapat dikatakan mudah dan tidak berbelit, karena dari pasien dan pihak pelaksana program BPJS Kesehatan di RSUD sudah mengetahui prosedur dalam pelayanan. Tetapi dari segi administrasi pendaftaran dan prosedur layanan masih terdapat ketidakpahaman para peserta dan pihak pelaksana teknis yang belum memahami bagaimana prosesnya. Hal ini tentunya menjadi penghambat kedepannya ketika masyarakat peserta BPJS bertanya kepada mereka bagaimana proses pendaftaran peserta ataupun proses pengambilan obat, sehingga dari segi pelayanan menjadi terlambat. Untuk mengatasi masalah tersebut Unsur Pimpinan RSUD atau TIM Pelaksana BPJS bisa mengadakan 
sosialisasi tentang prosedur pelayanan kepada para pelaksana teknis tersebut (dokter, perawat dan bidan), sehingga implementasi program BPJS tidak hanya diketahui oleh TIM Pelaksana BPJS tetapi dipahami oleh seluruh Staf/Pegawai RSUD Pambalah Batung Amuntai.

\section{Sumber Daya (Staf)}

Sumber daya dari segi staf yang tersedia belum bisa dikatakan cukup. Karena belum sebandingnya antara perawat dengan tempat tidur pasien. Dalam peraturan Kepmenkes Tahun 2008 tentang standar minimal pelayanan menyatakan bahwa dalam satu ruangan, tempat tidur berbanding 2:3 dengan perawat. Di RSUD Pambalah Batung Amuntai di ruang instalasi rawat Inap Kelas III jumlah tempat tidur berbanding 2:1 dengan jumlah perawat. Dari segi kemampuan staf masih banyak staf yang berpendidikan Diploma 3 (51\%), padahal diploma 3 berdasarkan Peraturan Kepmenkes tahun 2008 merupakan pendidikan minimal yang harus dimiliki pelayan kesehatan.

\section{Sarana dan Prasarana}

Sarana dan prasarana yang tersedia di RSUD Pambalah Batung Amuntai untuk kelas III belum memadai. Kurangnya sarana dan prasarana ini terutama yang berkaitan dengan peralatan medis, ruang tunggu dan fasilitas fisik lainnya. Padahal sarana dan prasarana yang tersedia di rumah sakit juga menjadi salah satu faktor yang penting dalam sebuah implementasi program BPJS Kebijakan. Berdasarkan hasil wawancara di atas bahwa dapat disimpulkan fasilitas yang tersedia dalam implementasi program BPJS Kesehatan pada RSUD Pambalah batung Amuntai sesuai dengan standar Kelas III dan standar RSUD yang bertipe $\mathrm{C}$, hanya saja belum cukup memadai dalam hal ketersediaan masih banyak fasilitas yang tidak berfungsi dengan maksimal (rusak) dan tidak dengan cepat diperbaiki

\section{Kecepatan Pelayanan}

Berdasarkan hasil wawancara dengan beberapa orang pasien dapat disimpulkan bahwa pihak rumah sakit masih kesulitan dalam mewujudkan pelayanan yang cepat. Terhambatnya pelayanan biasanya disebabkan karena tenaga medis khususnya dokter spesialis dan peralatan medis masih kurang sehingga sering pasien tidak bisa ditangani di RSUD Pambalah Batung dan harus dirujuk ke rumah sakit kabupaten terdekat. Terkadang dokter spesialisnya cuti sehingga keluhan pasien yang tidak bisa ditangani perawat dan dokter umum, pasien harus dirujuk ke rumah sakit kabupaten terdekat. Selain itu faktor keterbatasan peralatan medis yang dapat digunakan pada instalasi rawat inap juga merupakan hambatan tersendiri yang memunculkan masalah lain diluar kendali tenaga medis.

Adapun implementasi program jaminan sosial di bidang kesehatan Oleh BPJS Kesehatan dilihat dari teori Edward III keberhasilan implementasi kebijakan ditentukan oleh empat faktor penting. Pertama, Komunikasi, yaitu, saling mengerti dan memahami antara pihak penyelenggara BPJS Kesehatan dengan pemberi pelayanan (Puskesmas/Rumah Sakit) dan penerima layanan BPJS Kesehatan sesuai dengan hak dan kewajibannya masing-nasing. Kedua, Sumberdaya, baik berupa SDM dan pendanaan serta kualitasnya yang telah ditetapkan dalam pelaksanaan program tersebut. Ketiga, Disposisi, yaitu watak atau karakteristik dari pihak yang melaksanakan kebijakan sesuai dengan SOP BPJS Kesehatan seperti komitmen, kejujuran, konsistensi, dll. Keempat, Struktur birokrasi, merupakan bagian-bagian dalam pelaksanaan program BPJS Kesehatan yang menunjukan adanya tugas dan fungsi masingmasing antar bagian serta kejelasan koordinasinya.

Menyangkut empat variabel tersebut serta hasil wawancara kepada pihak-pihak yang terkait maka data dapat di analisis dan di deskripsikan sebagai berikut :

\section{Komunikasi \\ a. Transmisi}

Berdasarkan hasil pengamatan dan pernyataan dapat disimpulkan bahwa transmisi program BPJS Kesehatan di RSUD Pambalah Batung Amuntai telah dilaksanakan dengan baik, namun dalam hal dilapangan tidak semuanya memahami dan masalah yang ada dilapangan mengenai komunikasi tentang program BPJS tersebut tetap ada. Maka dapat 
disimpulkan bahwa transmisi atau penyaluran komunikasi yang baik antara semua pihak yang terkait dengan program BPJS Kesehatan pada RSUD Pambalah Batung Amuntai sangat berpengaruh terhadap keberhasilan program BPJS Kesehatan tersebut. Kedepannya diharapkan pihak BPJS bisa lebih gencar melakukan sosialisasi kepada masyarakat, baik itu dari segi procedural pendaftaran maupun dari segi maksud dan tujuan adanya BPJS, sehingga visi dari BPJS bisa berjalan dengan lancar. Sosialisasi tersebut bisa dilakukan dengan tatap muka langsung maupun melalui media cetak dan media televisi lokal yang ada di Kabupaten Hulu Sungai Utara. Selain itu Pihak BPJS juga sekiranya memberitahukan kepada peserta BPJS yang baru mendaftar tentang alur pelayanan yang diberikan pihak BPJS Kesehatan dengan hak dan kewajiban peserta. Pihak TIM Pelaksana BPJS yang ada di RSUD Pambalah Amuntai sekiranaya mamasang pamplet/banner tentang alur pelayanan bagi peserta BPJS yang terpampang disetiap ruang Rawat Inap.

\section{b. Kejelasan}

Dari segi kejelasan peraturan dapat disimpulkan bahwa belum adanya tahapan evaluasi dalam implementasi Program BPJS Kesehatan di RSUD Pambalah Batung Amuntai. Hal ini dikarenakan Program BPJS kesehatan belum $100 \%$ dilaksanakan, karena masih banyak persoalan-persoalan yang belum tuntas terkait dengan jaminan sosial lainnya seperti Askes, Jamkesmas, Pengguna Kartu Sehat Amuntai (KSA) dan sebagainya.

Dalam Peraturan BPJS Kesehatan yang tertuang dalam Perpres No. 12 Tahun 2013 pasal 6 Ayat 2 ada dua pentahapan yang dilakukan dalam implementasi Program BPJS yaitu:

Tahap pertama dimulai tanggal 1 Januari 2014, minimal meliputi:

1. Penerima Bantuan iuran (PBI) Jaminan Kesehatan

2. Anggota TNI/Pegawai Negeri Sipil di lingkungan Kementerian Pertahanan dan keluarganya.

3. Anggota POLRI/Pegawai Negeri Sipil di lingkungan POLRI dan keluarganya.
4. Peserta Asuransi Kesehatan Indonesia (ASKES) dan keluarganya.

5. Peserta Jaminan Sosial Tenaga Kerja (JAMSOSTEK) dan keluarganya.

Tahap kedua mencakup seluruh masyarakat Indonesia yang belum masuk sebagai peserta jaminan sosial berupa BPJS Kesehatan, diagendakan paling lambat tanggal 1 Januari 2019.

Dari uraian diatas, maka penulis menyimpulkan tahapan evaluasi dalam implementasi program BPJS di Kabupaten Hulu Sungai Utara belum ada. Di kabupaten Hulu Sungai Utara masih banyak pengguna PBI, Askes dan Jaminan Kesehatan lainnya yang belum tersinkronisasi dengan Program BPJS. Hal ini juga diakibatkan masih adanya aturanaturan prosedur administrasi yang berubahrubah. Contohnya 1 Juni 2015, kartu BPJS Kesehatan baru dapat digunakan setelah 14 hari pendaftaran, sebelumnya ketika peserta mendaftar dan membayar iuran langsung bisa mendapatkan pelayanan.

Berdasarkan hasil pengamatan dan wawancara tersebut, dapat disimpulkan bahwa dari pihak pelaksana di Program BPJS Kesehatan di RSUD Pambalah Batung Amuntai melakukan komunikasi dengan jelas dan baik dalam implementasi program BPJS Kesehatan tersebut tetapi masih perlu adanya tahapan evaluasi untuk mengukur tingkat komunikasi tersebut. Intensitas komunikasi dapat diukur dengan dilaksanakannya pertemuan bagi stakeholder atau pihak-pihak terkait untuk mengevaluasi pelaksanaan SOP dari program BPJS Kesehatan.

\section{c. Konsistensi}

Dalam hal ini suatu komunikasi tidak berubah-ubah dan jelas untuk diterapkan dan dijalankan, untuk menghindari kebingungan bagi pihak-pihak yang terkait dengan sebuah peraturan. Mengenai implementasi program BPJS Kesehatan menurut pengamatan dilapangan terdapat suatu perintah atau komunikasi yang berubah-ubah.

Berdasarkan pengamatan penulis, perubahan-perubahan yang terjadi hanya bersifat administratif, artinya tidak berpengaruh besar 
terhadap pelayanan kepada pasien di RSUD Pambalah Batung Amuntai. Perubahan yang terjadi seperti pendaftaran peserta mandiri harus juga mendaftarkan anggota keluarga yang tertera dalam kartu keluarga, setelah pendaftaran sebagai anggota baru bisa 14 hari mendapatkan pelayanan dan sebagainya.

Berdasarkan hasil pengamatan dan wawancara di atas, dapat disimpulkan bahwa dalam implementasi program Jaminan Kesehatan Nasional Oleh BPJS Kesehatan walaupun sering terjadi perubahan komunikasi hal tersebut tidak menjadi masalah, sebab pihak pelaksana implementasi program BPJS Kesehatan pada RSUD Pambalah Batung Amuntai cepat dan tanggap terhadap perubahan komunikasi yang terjadi. Hal ini menggambarkan adanya keharmonisan komunikasi yang terjalin oleh semua pihak pelaksana implementasi program BPJS Kesehatan pada RSUD Pambalah Batung Amuntai.

\section{Sumber Daya}

Perintah-perintah implementasi program Jaminan Kesehatan Nasional (JKN) Oleh BPJS Kesehatan mungkin diteruskan secara cermat, jelas dan konsisten, tetapi jika para pelaksana kekurangan sumber daya yang diperlukan untuk melaksanakan kebijakan-kebijakan, maka implementasi pun cenderung tidak efektif. Dengan demikian sumber daya dapat merupakan faktor-faktor yang penting dalam melaksanakan kebijakan publik.Mengenai masalah sumber daya dalam implementasi program BPJS Kesehatan ini, indikator yang dapat digunakan dalam mengukur keberhasilan sumber daya tersebut diantaranya yaitu Staf, Informasi, Wewenang dan Fasilitas.

\section{a. Staf}

Berdasarkan pengamatan dan hasil dokumentasi penulis, sumber daya dari segi staf yang tersedia belum bisa dikatakan cukup. Karena belum sebandingnya antara perawat dengan tempat tidur pasien. Dalam peraturan Kepmenkes Tahun 2008 tentang standar minimal pelayanan menyatakan bahwa dalam satu ruangan, tempat tidur berbanding 2:3 dengan perawat. Di RSUD Pambalah Batung
Amuntai di ruang instalasi rawat Inap Kelas III jumlah tempat tidur berbanding 2:1 dengan jumlah perawat. Dari segi kemampuan staf masih banyak staf yang berpendidikan Diploma 3 (51\%), padahal diploma 3 berdasarkan Peraturan Kepmenkes tahun 2008 merupakan pendidikan minimal yang harus dimiliki pelayan kesehatan.

Berdasarkan hasil pengamatan dan wawancara dapat disimpulkan bahwa sumberdaya yaitu staf ada pada RSUD belum memenuhi standar, baik dari jumlah maupun keahlian dan kemampuan yang mereka miliki.. Sesuai dengan pendapat di atas maka dalam implementasi program BPJS Kesehatan ini memiliki hambatan masalah sumberdaya yaitu staf yang ada pada RSUD Pambalah Batung Amuntai masih kurang.

\section{b. Informasi}

Sumberdaya mengenai informasi ini mengenai bagaimana cara melaksanakan kebijakan, implementor atau para pelaksana kebijakan harus mengetahui apa yang harus mereka lakukan disaat diberi perintah untuk melakukan tindakan.

Berdasarkan hasil wawancara dapat disimpulkan bahwa informasi tentang program JKN Oleh BPJS Kesehatan pada RSUD Pambalah Batung Amuntai ini berjalan dengan baik. Dengan informasi yang didapat kelurga pasien tentang program BPJS Kesehatan memberikan kejelasan kepada mereka tentang hak dan kewajiban mereka sebagai pasien BPJS Kesehatan, yaitu hak mereka mendapatkan pelayanan kesehatan, obat-obatan maupun kamar kelas sesuai pilihan pasien pada waktu mendaftar dan kewajiban mereka untuk menjadi peserta BPJS Kesehatan harus membayar iuran sesuai kelas yang mereka pilih. Selain itu juga Tim pengelola BPJS Kesehatan, menunjukkan bahwa pihak RSUD Pambalah Batung Amuntai juga turut memberikan informasi tentang program BPJS Kesehatan ini kepada seluruh masyarakat khususnya kepada pasien. Maka dapat disimpulkan sumberdaya mengenai informasi implementasi Program BPJS Kesehatan sudah berjalan dengan semestinya, tinggal bagaimana para pihak pelaksanaan dalam memberikan pelayanan sesuai dengan apa yang 
di informasikan atau apakah sudah sesuai dengan petunjuk teknis pelaksanaan implementasi program BPJS Kesehatan tersebut.

\section{c. Wewenang}

Dalam hal implementasi program BPJS Kesehatan, para pihak pelaksana semestinya melaksanakan tugasnya sesuai dengan petunjuk teknis pelaksanaan program BPJS tersebut, agar tidak ada terjadi penyimpangan wewenang dalam pelaksanaan implementasi Program BPJS Kesehatan ini. Dari hasil wawancara dapat disimpulkan bahwa pelaksanaan wewenang atas tugas yang diperintahkan berkenaan dengan implementasi program BPJS Kesehatan terhadap pihak pelaksana dalam hal ini yaitu perawat dan bidan yang ada pada ruang rawat inap pada RSUD berjalan dengan semestinya sesuai dengan yang diharapkan.

\section{d. Fasilitas}

Fasilitas merupakan unsur penunjang dalam implementasi sebuah kebijakan. Jika staf yang dimiliki telah mencukupi dan memadai serta mengetahui apa yang harus dikerjakannya, wewenang yang diberikan juga telah terlegitimasi, sementara fasilitas pendukung (sarana dan prasarana) tidak tersedia, tentu saja implementasinya berjalan dengan timpang. Dalam hal fasilitas pada pelaksanaan program BPJS Kesehatan ini yang sangat mempengaruhi jalannya pelaksanaannya dilapangan yaitu bagaimana kuantitas dan kualitas fasilitas yang ada pada RSUD Pambalah Batung dalam program BPJS Kesehatan tersebut.

Dalam hal fasilitas ini, peneliti banyak mendapati permasalahan baik dari pihak pelaksananya maupun dari masyarakat atau pasien pengguna kartu BPJS Kesehatan selama melaksanakan pengamatan. Hasil wawancara menggambarkan bahwa sarana dan prasarana yang tersedia di RSUD Pambalah Batung Amuntai terutama untuk kelas III belum memadai. Kurangnya sarana dan prasarana ini terutama yang berkaitan dengan peralatan medis, ruang tunggu dan fasilitas fisik lainnya. Padahal sarana dan prasarana yang tersedia di rumah sakit juga menjadi salah satu faktor yang penting dalam sebuah implementasi program BPJS Kesehatan. Sebetulnya fasilitas yang tersedia pada RSUD Pambalah batung Amuntai dapat dikatakan cukup baik sesuai dengan standar Kelas III dan standar RSUD bertipe C, hanya saja belum cukup memadai dalam hal ketersediaan masih banyak fasiltas yang tidak berfungsi dengan maksimal (rusak) dan tidak dengan cepat diperbaiki.

\section{Disposisi}

Disposisi atau sikap para pelaksana dalam hal ini pihak RSUD akan menimbulkan masalah dan hambatan terhadap implementasi kebijakan bila personil yang ada tidak melaksanakan program BPJS Kesehatan ini dengan baik. Karena itu, dalam pemilihan dan pengangkatan unsur pelaksana kebijakan haruslah orang-orang yang memiliki komitmen dan dedikasi pada kebijakan yang telah ditetapkan, lebih khusus lagi pada kepentingan warga masyarakat khususnya pasien pengguna BPJS Kesehatan. Ada dua indikator yang harus dicermati dalam variable disposisi, yaitu pengangkatan birokrat dan insentif.

\section{a. Pengangkatan birokrat}

Berdasarkan hasil wawancara, dapat disimpulkan bahwa, pengangkatan pegawai di RSUD Pambalah Batung sudah sesuai dengan kemampuan dalam bekerja sehingga implementasi program BPJS Kesehatan bisa berjalan dengan efektif, karena didukung oleh pelaksana yang kompeten dan mempunyai skill yang bagus dalam melaksanakan tugas pada RSUD Pambalah Batung Amuntai tersebut.

\section{b. Insentif}

Menurut Edward III dalam Nawawi, salah satu cara untuk memotivasi para pelaksana untuk melaksanakan kebijakan adalah dengan memberikan insentif, baik berupa keuntungan maupun biaya tertentu. Berdasarkan hasil wawancara, dapat disimpulkan bahwa dari segi insentif, sudah mencukupi sehingga dapat mencegah adanya pihak-pihak yang melakukan pungutan biaya kepada warga yang menggunakan program BPJS Kesehatan ini. Selain itu Insentif yang diberikan pihak BPJS berdampak positif terhadap semua karyawan, dikarenakan dengan adanya insentif tersebut 
memberikan tambahan penghasilan bagi karyawan RSUD Pambalah Batung Amuntai.

\section{Struktur Birokrasi}

Menurut George C. Edward III di dalam birokrasi selalu terdapat SOP (Standard Operating Procedures) dan Fragmentasi. SOP merupakan rutinitas-rutinitas yang memungkinkan para pejabat publik membuat sejumlah besar keputusan umum sehari-hari dan ia merupakan jawaban terhadap keterbatasan waktu dari sumber daya pelaksana organisasi yang kompleks dan beragam. Sedangkan fragmentasi adalah pembagian tanggung jawab suatu daerah kebijakan di antara beberapa unit organisasi. SOP dan fragmentasi dapat mempengaruhi bahan-bahan dalam kebijakan memboroskan sumber daya, meningkatkan tindakan yang diinginkan, menghambat koordinasi dan membingungkan pejabat di tingkat bawah.

Dari pengamatan peneliti SOP (Standard Operating Procedurs) dan fragmentasi sudah memenuhi standar yang dilaksanakan, ini bisa dilihat pada pihak pelaksana implementasi BPJS Kesehatan yang ada pada RSUD yang sudah memenuhi standar dalam pelayanan kesehatan dan dalam pelaksanaannya dilapanganpun tekoordinir secara baik dengan tanggung jawab dan tugas masing-masing pada semua pihak yang berkaitan dalam implementasi program BPJS Kesehatan ini, sesuai dengan Surat Keputusan Direktur RSUD Pambalah Batung Amuntai Nomor 14 tahun 2014 tentang TIM JKN, dengan adanya surat keputusan tersebut memberikan kejelasan tanggungjawab atas tugas para pihak pelaksana dalam implementasi program BPJS Kesehatan ini.

\section{KESIMPULAN}

1. Implementasi Program BPJS Kesehatan pada Rumah Sakit Umum Daerah (RSUD) Pambalah Batung Amuntai Kabupaten Hulu Sungai Utara sudah berjalan maksimal namun masih adanya kekurangan dalam proses implementasinya. Pertama, masih adanya masyarakat yang belum mengetahui dengan persis bagaimana prosedur pelayanan administrasi peserta BPJS Kesehatan Kelas
III di RSUD Pambalah Batung Amuntai. Kedua, Sarana dan prasarana pelayanan yang masih belum memadai terutama yang berkaitan dengan fasilitas fisik dan peralatan medis. Keterbatasan ini disebabkan karena keterbatasan anggaran rumah sakit. Ketiga,, Kecepatan pelayanan masih terkendala dengan kurangnya tenaga medis terutama dokter spesialis dan peralatan medis yang ada di rumah sakit. Kekurangan jumlah tenaga medis dan peralatan medis masih disebabkan anggaran dana dirumah sakit yang masih terbatas. Keempat, Untuk pelayanan medis masih terdapat perbedaan pemberian jenis obat (paten \& generic) dan fasilitas ruangan pasien rawat inap antara pasien umum dengan pasien BPJS, Jdan kelas III gratis. Kelima, Dalam memberikan pelayanan petugasnya ramah dan sopan sehingga membuat pasien merasa tenang dan nyaman.

2. Faktor-faktor yang mempengaruhi Implementasi Program BPJS Kesehatan pada RSUD Pambalah Batung Amuntai dipengaruhi beberapa faktor: 1. Komunikasi, 2. Sumber Daya, 3, Disposisi dan 4, Struktur Birokrasi.

3. Kendala - kendala yang dihadapi dalam implementasi Program BPJS Kesehatan pada RSUD Rumah Sakit Umum Daerah (RSUD) Pambalah Batung Amuntai Kabupaten Hulu Sungai Utara antara lain: Dari aspek Komunikasi dalam hal ketidak jelasannya komunikasi yang mengakibatakan terhambatnya proses pelayanan yang dilakukan oleh pihak Pelaksana pada RSUD Pambalah Batung Amuntai, dan dari pihak masyarakat belum mengetahui seluruhnya tentang program BPJS Kesehatan. Kemudian Aspek Sumber Daya fasilitas RSUD yaitu fasilitas untuk pasien masih kurang dan belum cukup memadai karena masih banyak fasilitas kesehatan yang tidak berfungsi dengan baik dan mengalami kerusakan. Masalah lain dalam hal Sumber daya yang paling utama dalam implementasi adalah staf, bahwa staf yang ada pada RSUD belum memenuhi standar, baik dari jumlah, keahlian maupun kemampuan yang mereka miliki, dan masih perlu adanya analisis. Aspek lainnya mengenai Sumber daya yaitu fasilitas sarana 
prasarana yang belum cukup seperti internet (wifi) di IGD untuk petugas pelaksana kepada pasien BPJS Kesehatan yang tidak ada, karena belum adanya internet di IGD sehingga sebagai pihak RSUD tidak bisa mengetahui apakah pasien tersebut masih terdaftar sebagai pasien BPJS atau tidak.

\section{REFERENSI}

Abdul Wahab, Solichin,. 2005. Analisis Kebijaksanaan. Jakarta: Bumi Aksara.

Agustino, Leo,. 2006. Dasar-Dasar Kebijakan Publik. Malang: Universitas Muhammadiyah Malang.

Dunn,William N, 2003. Pengantar Analisis Kebijakan Publik. Yogyakarta,Gadjah Mada University Press.

Inu Kencana, Welasari, 2015. Ilmu Administrasi: Pustaka Belajar.

Moleong, Lexy J,. 2004. Metodologi Penelitian Kualitatif. Bandung: PT Remaja Rosdakarya.

Narbuko,Cholid dan Achmadi, Abu. 2007. Metode Penelitian. Jakarta: Bumi Aksara

Putri, Asih Eka. 2014. Seri Buku 2 Paham BPJS (Badan Penyelenggaraan Jaminan Sosial). Jakarta: Friedrich Ebert Stiftung

Rewansyah, Asnawi. 2010. Reformasi Birokrasi dalam rangka Good Governence. Jakarta : Yusaintanas Prima.

Sogiyono, 2013. Metode Penelitian Kuantitatif Kualitati Dan R\&D. Bandung, Cetakan ke Tiga Belas:Alfabeta.

Wahyu dkk. 2007. Pedoman Penulisan Karya Ilmiah". FKIP Unlam. Banjarmasin

Widodo, Joko. 2009. Analisis Kebijakan Publik. Bayu Media Publishing. Malang.

Winarno, Budi. 2005. Teori dan Proses Kebijakan Publik. Media Press Yogyakarta.
Kementerian Kesehatan RI. 2013. Buku Pegangan Sosialisasi Jaminan Kesehatan Nasional (JKN) dalam Sistem Jaminan Sosial Nasional. Kemenkes RI. Jakarta: Kemenkes.

Keputusan Menteri Pendayagunaan Aparatur Negara Nomor 63 Tahun 2013. Tentang Pedoman Umum Penyelenggaraan Pelayanan Publik. Jakarta : Menteri Pendayagunaan Aparatur Negara.

Undang-Undang Republik Indonesia Nomor 24 Tahun 2011. Tentang Badan Penyelenggara Jaminan Sosial. Jakarta: Kementerian Kesehatan. 